\title{
ІСТОРИЧНІ ПЕРЕДУМОВИ
}

\section{ФОРМУВАННЯ ДЕОНТОЛОГІЧНОЇ КОМПЕТЕНТНОСТІ ФАХІВЦІВ У ГАЛУЗІ ОХОРОНИ ЗДОРОВ'Я}

УДК 37.012.2+614.253

DOI: $10.12958 / 2227-2747-2021-3(178)-77-87$

Гужва Олена Іванівна, кандидат біологічних наук, доцент кафедри фізичної терапії, ерготерапії та здоров’я людини Д3 «Луганський національний університет імені Тараса Шевченка», м. Старобільськ, Україна gujva.elena@gmail.com https://orcid.org/0000-0002-6627-8203

Для цитування: Гужва О. І. Історичні передумови формування деонтологічної компетентності фахівців у галузі охорони здоров'я. Освіта ma педагогічна наука. 2021. № 3 (178). С. 77-87.

References (стандарт APA): Huzhva, O. I. (2021). Istorychni peredumovy formuvannia deontolohichnoi kompetentnosti fakhivtsiv u haluzi okhorony zdorovia [Historical Preconditions for the Formation of Deontological Competence of Specialists in the Field of Health Care]. Osvita ta pedahohichna nauka - Education and Pedagogical Sciences, 3 (178), 77-87 [in Ukrainian].

Постановка проблеми. Підготовка фахівців у галузі охорони здоров'я передбачає формування певних професійних компетентностей, зокрема деонтологічної, яка $\epsilon$ основою клінічного мислення професіоналів медичної сфери. Деонтологічна компетентність - це властивість особистості фахівця, яка дозволяє йому продуктивно взаємодіяти 3 внутрішнім (професійним) і зовнішнім (соціальним) середовищем завдяки наявності деонтологічних знань, умінь і навичок, що забезпечують успішну особистісно-професійну взаємодію 3 пацієнтами, ефективну організацію та вирішення професійних завдань (Костомарова, 2013, с. 112). Водночас розуміння сутності деонтологічної компетентності неможливе без розгляду історичних передумов виникнення профе- сійної етики, зокрема в галузі охорони здоров'я.

Аналіз актуальних досліджень. Аналіз літературних джерел показав, що питанням медичної деонтології присвячено праці багатьох вітчизняних та зарубіжних науковців. Так, А. Чумак, В. Мовчан, Р. Чайковський та ін. проводили ретроспективний аналіз професійної етики; Ю. Віленський, П. Назар, Н. Пасєчко та ін. вивчали питання медичної етики. Розвиток ідей деонтології розглядали О. Михайленко, Н. Сокольський, Г. Степанівська та ін.; 
історичні аспекти професійної етики та деонтології досліджували Н. Бірюкова, Л. Дудікова, А. Котвіцька та ін.

Мета статті - проаналізувати історичні передумови формування деонтологічної компетентності фахівців у галузі охорони здоров'я.

\section{Методологія та методи дослідження.}

Для досягнення мети використано комплекс теоретичних методів дослідження, який включав історико-педагогічний та порівняльний аналіз основних етапів формування та розвитку ідей деонтології та професійної етики в галузі охорони здоров'я.

Виклад основного матеріалу. Історія зародження деонтології сягає глибокої давнини. 3 початком відокремлення в суспільстві різних професійних груп виникають питання, пов'язані з унормуванням особистісних та професійних взаємин у системах «учитель - учень», «продавець - покупець», «лікар - пацієнт» та ін.; необхідність регулювання професійної поведінки природно призводить до появи певних етичних норм, з'являється поняття «деонтологія» як наука про людський та професійний обов'язок (Ибрагимова, Абдурахимова, 2019).

Перші згадки про медичну деонтологію та етику трапляються в стародавніх текстах Сходу, Сгипту та Персії, Риму та Стародавньої Греції. Так, у приписах Стародавнього Єгипту чітко окреслено риси майбутнього лікаря - доброта, терпіння та сміливість. У Стародавній Індії зазначали, що учень, який хоче віддати своє життя медицині, повинен мати перш за все велике бажання та наполегливість вивчати науку медицини, бути благородним, мудрим та справедливим (Çірі, 2015, p. 370 ).

Аналізуючи історичний розвиток медичної деонтології, констатуємо, що кожний історичний період характеризувався специфічними саме для цієї епохи етичними принципами, сформульованими відповідно до наявних моральних норм. Так, у Стародавній Індії лікарям дозволялося не братися за лікування тяжкохворих пацієнтів. Етичний кодекс Стародавнього Тибету вимагав від лікарів розуміння своїх обов'язків, знання різноманітних наук та здібностей до лікарської професії. Етичним принципам Середньовічного Китаю, викладеним у праці «Тисяча золотих ліків», була притаманна гуманність щодо пацієнта, незалежно від соціального статусу всі хворі повинні були отримувати однакове лікування, на відміну від Персії, де був упроваджений диференційований підхід до хворих (Котвіцька, Кубарєва, Горбаньов, 2019, с. 77).

Важливим етапом розвитку професійної медичної етики є вчення давньогрецького лікаря, філософа Гіппократа (460-377 до н. е.), який уперше систематизував основні правила лікарської поведінки з урахуванням наявного медичного досвіду. Віддзеркалення думок Гіппократа можна знайти в його працях «Про доброзичливу поведінку», «Про лікаря», «Настанови», «Про природу людини» та ін., у яких автор приділяє велику увагу питанням взаємодії лікаря з пацієнтом та його рідиною, а також взаєминам між колегами-медиками (Panova, 2016, p. 182).

Медична етика Гіппократа, яка здобула визнання в багатьох країнах світу, грунтується на гуманності, справедливості, доброті, безкорисливості, повазі до інших, незалежно від матеріального становища, віку та статі. У демократичних поглядах «батька медицини» Гіппократа не було відмінностей між рабами та вільними, до всіх людей було гуманне та турботливе ставлення, що не притаманно поглядам інших філософів Стародавньої Греції - Платона та Аристотеля, які відмовляли рабам у праві називатися людьми і вважали їхнє становище приреченим (Колісник-Гуменюк, 2010, с. 9; Дудікова, 2017, с. 323). 
Одним 3 найбільших досягнень Гіппократа $є$ збірник етичних правил, відомий як «Клятва (Кодекс) Гіппократа» ( $\mathrm{V}$ ст. до н. е.), у якому визначено основні ціннісні орієнтири та принципи лікарської професії. Важливість етичних поглядів, викладених у збірці, підтверджуєте, що саме «Клятва Гіппократа» стала основою для створення багатьох сучасних професійних етичних кодексів, зокрема «Женевської декларації» (1947р.) (Вербовська, 2019, с. 238).

Отже, саме гіппократівська етика заклала основу сучасних поглядів на медичну деонтологію та слугувала предтечею ранніх пацієнтоцентрованих моделей, які були зосереджені на особливостях міжособистісної взаємодії медичних працівників та пацієнтів.

Деонтологічні ідеї Гіппократа отримали подальший розвиток у працях багатьох відомих учених-філософів та лікарів. Так, перський лікар Абу Бакрар Разі (865-925 рр.) писав, що основна мета лікаря полягає в добрі, навіть у ставленні до ворогів, а цілитель повинен бути освіченою та розумною людиною, який не вправі робити будь-яку шкоду (Biryukova et al., 2021, p. 78).

У працях перського лікаря та філософа Абу Алі Ібн Сіни (Авіценна, 980-1037рр.) підкреслено необхідність індивідуального підходу до кожного пацієнта, звернено увагу на обов'язок лікаря бути відданим і доброзичливим до пацієнтів (Biryukov, Biryukova, \& Nesterova, 2020, p. 122).

Єврейський філософ та лікар Моше Бен Маймон (Мойсей Маймонід, 11351204 рр.) у своїх працях узагальнив досягнення арабської та єврейської медицини, сформулювавши власний етичний постулат: «...зміни силу серця мого так, щоб воно готово було завжди однаково служити бідним i багатим, друзям і ворогам, добру і злу...» (Biryukov, Biryukova, \& Nesterova, 2020, p. 122).
Одним 3 відомих середньовічних літературних джерел з медичної етики є варіант клятви Гіппократа запропонований лікарем і мислителем Парацельсом (Філіп Ауреол Теофраст Бомбаст фон Гогенгайм, 1493-1541 pр.), у якій автор пише «Я прагну любити хворих більше, ніж самого себе», а також зазначає, що головними професійними чеснотами лікаря у спілкуванні 3 пацієнтами є милосердя та співчуття (Бушля, Бударин, 2012, с. 61).

У XVIII ст. в Англії шотландський лікар Джон Грегорі (1724-1773 рр.) у своій праці «Лекції про обов'язки та кваліфікацію лікаря» (1772 р.) привертає увагу до вміння лікаря «відчувати» пацієнта, «вживатися» в його переживання (Пономарева, Штукерт, 2019).

На початку XIX ст. 3'являється праця Томаса Персіваля (1740-1804рр.) «Медична етика, або Збірка встановлених правил стосовно професійної поведінки лікарів і хірургів» (1803 р.), яка в подальшому стала основою «Етичного кодексу лікаря» і розкривала важливі питання, що стосувалися ціннісних орієнтирів лікаря при виконанні професійних обов'язків, а також взаємин між пацієнтами та лікарями, лікарями та медичним персоналом тощо (Пономарева, Штукерт, 2019; Гужва, 2021, с. 19).

На теренах Російської імперії, до складу якої входила Україна, одним із фундаторів медичної деонтології був видатний лікар, професор Матвій Якович Мудров (1776-1831рр.), який у своїй промові «Слово про спосіб вчити та вчитися медицини практичного чи діяльного лікарського мистецтва при ліжках хворих» (1820 р.) в Імператорському Московському університеті, наставляючи студентів, говорив: «Почавши 3 любові до ближнього, я повинен би навіяти вам усе інше, що випливає 3 цієї лікарської чесноти, а саме: послужливість, готов- 
ність до допомоги в будь-який час, i вдень і вночі; привітність, що привертає себе боязких і сміливих; милосердя до чужоземних та бідних; безкорисливість; поблажливість до погрішностей хворих; лагідну строгість до їх непослуху; ... скромність і сором'язливість у всякому разі; ... зберігання таємниці та скритність при хворобах поганих; мовчання про бачені чи почуті сімейні безлади; ... цнотливість, благочестя, богошанування внутрішне та зовнішнє; підкорення самого себе...» (1820 р.) (Мудров, 1968, с. 94). Саме М. Я. Мудров у своїй іншій промові «Слово про благочестя і моральні якості гіппократова лікаря» (1813 р.) уперше представив російськомовний переклад клятви Гіппократа: «Вчення великого Гіппократа, за неймовірними труднощами перекладу, досі не існувало для російського юнацтва, і ніхто ще не наважувався перекладати його...Викликати цього фенікса 3 тління я вважаю зухвалістю і разом тим славою» (Мудров, 2009, с. 119).

Питаннями медичної етики також займався лікар-терапевт, фізіолог С. Боткін, який писав про необхідність створення сучасного етичного кодексу лікаря. Окремі етичні питання порушували у своїх працях М. Пирогов, І. Павлов, І. Сєченов та ін. (Колісник-Гуменюк, 2010; Левенець, 2012; Пономарева, Штукерт, 2019; Biryukov, Biryukova, Nesterova, 2020).

Вагомий внесок у розвиток деонтології зробив російський лікар-хірург та вчений М. М. Петров (1876-1964 рр.), який уперше ввів поняття медичної деонтології в російськомовну медичну літературу (Чебан, 2014; Біла, 2020).

На сьогодні основою регулювання взаємин між лікарем і пацієнтом слугує низка нормативно-правових документів та етичних кодексів. Основними міжнародними документами, що визначають етичні норми поведінки лікаря та регламентують роботу медичних працівників, є Женевська декларація (1948р.), Міжнародний кодекс медичної етики (1949р.), Гельсінська декларація (1964р.), Токійська декларація (1975 р.), Лісабонська декларація стосовно прав пацієнта (1981р.), Декларація стосовно незалежності та професійної свободи лікаря (1986р.), Мадридська декларація стосовно професійної автономії і самоуправління (1987р.), Положення про захист прав і конфіденційності пацієнта (1993р.) та ін. (Левенець, 2012; Чебан, 2014; Бачинська, 2016; Біла, 2020).

Заснована на клятві Гіппократа Женевська декларація була прийнята Другою Генеральною асамблеєю Всесвітньої медичної асоціації у вересні 1948 р.(Женевська декларація, 1948); у вересні 1994 р. затверджена остання версія декларації. Це основний міжнародний документ, який містить базові етичні принципи лікарської професії, викладені у вигляді присяги.

Міжнародний кодекс медичної ети$\kappa и$ прийнятий у 1949 р. у Лондоні Третьою Генеральною асамблеєю Всесвітньої медичної асоціації (Міжнародний кодекс медичної етики, 1949); документ переглядався та доповнювався рішеннями 22-ї Всесвітньої медичної асамблеї (серпень 1968 р.) та 35-ї Всесвітньої медичної асамблеї (жовтень 1983 р.). Кодекс доповнює та розширює етичні принципи, викладені в Женевській декларації, окреслюючи загальні обов'язки лікаря, види діяльності, що визнаються неетичними, та особливості взаємин лікаря з пацієнтами та колегами.

Гельсінська декларація Всесвітньої медичної асоціації «Етичні принципи медичних досліджень за участю людини у якості об'єкта дослідження» прийнята 18ою Генеральною асамблеєю ВСМ у червні 1964 р.; була доповнена та переглянута вісім разів (1975, 1983, 1989, 1996, 2000, 
2002, 2004, 2008 рр.) (Гельсінська декларація, 1964). Гельсінська декларація є основним міжнародним документом, що регламентує «етичні принципи медичних досліджень за участю людини у якості об'єкта дослідження» і визначає загальні принципи медичних досліджень та принципи медичних досліджень, поєднаних 3 медичною допомогою. Покликаючись на інші кодекси, Гельсінська декларація визначає базові етичні принципи: «Здоров’я мого пацієнта буде основним моїм клопотом» (Женевська декларація, 1948) та «Надаючи медичну допомогу, лікареві належить діяти виключно в інтересах пацієнта» (Міжнародний кодекс медичної етики, 1949).

Токійська декларащчія, прийнята 29ою Всесвітньою медичною асамблеєю (Токіо, 1975 р.), визначає позицію лікарів стосовно тортур чи інших форм жорстокого, негуманного або принизливого поводження в разі затримання або ув'язнення, наголошуючи на тому, що «винятковим правом лікаря є здійснення медичної діяльності в ім'я людяності, запобігання та відновлення фізичного та психічного здоров'я, незважаючи на особистість пацієнта, зменшення та полегшення страждань його пацієнтів» (Токійська декларація, 1975).

Лісабонська декларачія стосовно прав пацієнта, прийнята 34-ою Всесвітньою медичною асамблеєю у 1981 р., описує основні права, які медики повинні намагатися надавати пацієнтам, і наголошує на тому, що «...лікар завжди повинен діяти згідно зі своєю совістю та завжди у вищих інтересах свого пацієнта» (Лісабонська декларація, 1981).

Принципи Лісабонської декларації щодо захисту прав пацієнта, отримали подальший розвиток у Положенні про захист прав і конфіденційності пацієнта, прийнятому 45-ою Всесвітньою медичною асамблеєю у 1993 р., у якому зазначено: «... етичний та професійний обов'язок [лікаря] ді- яти у кращих інтересах пацієнта у будьякий час» (Положення про захист прав $\mathrm{i}$ конфіденційності пацієнта, 1993).

Питання професійної автономії, незалежності лікаря та свободи щодо ухвалення рішень на користь пацієнта викладені в Декларачії про незалежність $i$ професійну свободу лікаря, прийнятої 38ою Всесвітньою медичною асамблеєю (жовтень, 1986 р.) (Декларація про незалежність і професійну свободу лікаря, 1986), та Мадридській декларачії стосовно професіональної автономіі $і$ самоуправління, 39-ою Всесвітньою медичною асамблеєю (жовтень, 1987 р.) (Мадридська декларація, 1986).

Формування й розвиток громадянського суспільства в Україні зумовили появу низки вітчизняних нормативних актів у галузі медичної етики та деонтології. Так, Указом Президента України № 349 від 15 червня 1992 р. була затверджена Клятва лікаря (Клятва лікаря, 1992).

Про необхідність «дотримуватися вимог професійної етики і деонтології, зберігати лікарську таємницю» наголошує Закон України «Основи законодавства Украӥни про охорону здоров'я» (остання редакція від 20.10.2021 р.). У Ст. 76 Закону також указано, що «випускники медичних спеціальностей вищих медичних навчальних закладів приносять Присягу лікаря України. Текст Присяги лікаря України затверджується Кабінетом Міністрів України» (Основи законодавства України про охорону здоров'я, 1992).

27 вересня 2009 року на X 3'їзді Всеукраїнського лікарського товариства було прийнято Етичний кодекс лікаря Украӥни, фундаментальними положеннями якого $\epsilon$ повага до пацієнта, життя та здоров'я людини від народження до смерті. Професійна діяльність лікаря повинна бути спрямована на «збереження та захист життя й здоров'я людини ... зменшення страждань при 
невиліковних хворобах, при народженні і настанні смерті». Моральні засади Етичного кодексу лікаря України було складено на основі положень міжнародних документів: Міжнародного кодексу лікарської етики, Гельсінської декларації, Загальної декларації про геном і права людини й Конвенції про захист прав та гідності людини з огляду на застосування досягнень біології та медицини. Кодекс включає рекомендації щодо його застосування, визначає морально-етичні принципи взаємодії лікаря з пацієнтами та колегами, окреслює етичні вимоги до проведення біомедичних досліджень за участю пацієнта тощо. Положення Кодексу необхідно виконувати лікарям, адміністративному персоналу і науковцям, які мають безпосереднє відношення до лікувально-профілактичної та наукової діяльності в галузі охорони здоров'я (Етичний кодекс лікаря України, 2009; Левенець, 2012).

Висновки та перспективи подальших досліджень. Отже, морально-етичні принципи та правила професійної поведінки в галузі охорони здоров'я формувалися, змінювалися та вдосконалювалися впродовж історичного розвитку, водночас відбувався зсув акценту 3 міжособистісних взаємин пацієнта та лікаря на забезпечення етичності всієї системи охорони здоров'я.

На сьогодні, спираючись на історичні передумови, на міжнародному та національному рівнях розроблено й упроваджено низку нормативних документів, які окреслюють етичні принципи, моральні засади та норми поведінки медичного працівника при виконанні своїх професійних обов'язків. Водночас соціальноекономічні зміни, стрімкий розвиток медицини, реформування системи охорони здоров'я та медичної освіти, прагнення наблизитись до європейських стандартів, упровадження нових моделей надання медичних послуг зумовлює необхідність удосконалення професійних компетентностей у медичній галузі, особливо за умов значної професійної конкуренції на ринку праці. Ураховуючи те, що деонтологічна компетентність $€$ невід'ємною частиною професійних компетентностей, у багатьох аспектах визначаючи професійний рівень фахівців у галузі охорони здоров'я, питання, пов'язані з удосконаленням відповідної нормативно-правової бази та процесом формуванням системи деонтологічних знань, умінь і навичок, набувають усе більшої актуальності та потребують негайного вирішення.

Перспективним напрямом подальших досліджень може бути розгляд сутності та структури деонтологічної компетентності фахівців у галузі охорони здоров'я, зокрема фізичних терапевтів та ерготерапевтів.

\section{Література}

Бачинська Л. Ю. Співвідношення медичної етики, медичної деонтології та біоетики. Науковий вісник Ужгородського національного університету. Серія ПРАВО. 2016. Вип. 37, Т. 3. С. 131-134.

Біла Н. І. Медична етика і деонтологія: реалії і перспективи в роботі сучасного медичного працівника. Актуальні проблеми методологї вищої медичної (фармацевтичної) освіти: сучасні виклики та нові можливості. Черкаси, 2020. C. $88-92$.

Бушля А. А., Бударин Г. Ю. Этика Парацельса. Социальное и пенсионное право. 2012. № 1 (9). С. 56-66.

Вербовська Р. I. Історичні передумови зародження медичної деонтології в античний період. Український журнал медищини, біологї та спорту. 2019. Т. 4, № 2 (18). C. 236-241.

Гельсінська декларація ВМА «Етичні принципи медичних досліджень за участю 
людини у якості об' єкта дослідження». URL: https://zakon.rada.gov.ua/laws/show/990_005.

Гужва О. І. Розвиток ідей деонтології та професійної етики в історичному аспекті. Вісник Луганського національного університету імені Тараса Шевченка. Педагогічні науки. 2021. № 6 (344), Ч. 1. C. 17-24.

Декларація стосовно незалежності та професійної свободи лікаря. URL: https://zakon.rada.gov.ua/laws/show/995_326.

Дудікова Л. В. Розвиток моральноетичних поглядів на лікарську діяльність в історичній спадщині. Професійна nidготовка фахівців: креативний підхід. Житомир : Вид-во Євенок О. О., 2017. C. 319-335.

Етичний кодекс лікаря України. URL: https://zakon.rada.gov.ua/rada/show/n000174809.

Женевская декларация. URL: https://zakon.rada.gov.ua/laws/show/990_001.

Ибрагимова X., Абдурахимова Н. Развитие этики и деонтологии. Мировая наука. 2019. № 6 (27). С. 197-200.

Колісник-Гуменюк Ю. І. Морально-етична складова професійної культури медичних працівників. Проблеми та перспективи формування національної гуманітарно-технічної еліти: зб. наук. пр. 2010. Вип. 27 (31), Ч. 2. С. 213-219.

Костомарова Е. В. Сущность и содержание деонтологической компетентности студента-медика. Международный научно-исследовательский журнал. 2013. № 8-3 (15). C. 111-113.

Котвіцька А. А., Кубарсва I. В., Горбаньов В. В. Дослідження історичних аспектів становлення та розвитку фармацевтичної етики і деонтології в Стародавньому світі. Сочіальна фармація: стан, проблеми та перспективи: матеріали $V$ Міжнар. наук.-практ. інтернет-конф. (м. Харків, 25-26 квіт. 2019 р.). Харків : НФаУ, 2019. C. 74-82.
Левенець С. С. Медична етика і деонтологія: реалії і перспективи в роботі лікаря. Медична освіта. 2012. № 4. С. 87-90.

Лиссабонская декларация относительно прав пациента. URL: https://zakon.rada.gov.ua/laws/show/990_016.

Мадридская декларация относительно профессиональной автономии и самоуправления. URL: https://zakon.rada.gov.ua/laws/show/990_025.

Міжнародний кодекс медичної етики. URL: https://zakon.rada.gov.ua/laws/show/990_002.

Мудров М. Я. Слово о способе учить и учиться медицине практической или деятельному врачебному искусству при постелях больных. Хрестоматия по истории медищиньл. Москва: Медицина, 1968. С. 94.

Мудров М. Я. Слово о благочестии и нравственных качествах гиппократова врача. Экспериментальная и клиническая гастроэнтерология. 2009. № 4. С. 118-126.

Основи законодавства України про охорону здоров'я: Закон України від 19.11.92 p. № 2802-XII (редакція від 20.10.2021 p.). URL: https://zakon.rada.gov.ua/laws/show/2801-12.

Положение о защите прав и конфиденциальности пациента. URL: https://zakon.rada.gov.ua/laws/show/990_056.

Пономарева А. А., Штукерт В. В. Исторические корни формирования деонтологических и этических аспектов врачебной деятельности. Долг врача: сб. материалов межрегион. науч.-практ. электрон. конф. Курск, 2019. С. 87-93.

Про Клятву лікаря. Указ Президента України від 15 червня 1992 року № 349. URL: https://zakon.rada.gov.ua/laws/show/349/92.

Токійська декларація. Основні лікарські принципи відносно катувань та інших видів жорстокого, негуманного або принизливого поводження або покарання при затриманні i взятті під варту. URL: https://zakon.rada.gov.ua/laws/show/990_011. 
Чебан В. Історичний аспект лікарської етики, біоетики та медичної деонтології. Актуальні питання суспільних наук та історії медицини. 2014. № 3 (3). C. 93-100.

Biryukov A., Biryukova N., Nesterova O. Evolution of ethical and deontological principles in the practice of medical workers based on priest-doctors life experience. European Journal of Science and Theology. 2020. Vol. 16, Issue 6. P. 121-129.

Biryukova, N. V., Kharina, A. S., Nesterova, N. V., \& Malakhovskiy, V. V. (2021). Historical aspects and features of deontology in preventive medicine. Journal of Advanced Pharmacy Education and Research. 2021. № 11(3). C. 77-82.

Çipi B. Deontology and its role in practice medicine in Albania. JAHR. 2015. Vol. 6/2, Issue 12. P. 367-374.

Panova E. L. On several prerequisites for the emergence of rational medicine according to Hippocratic Corpus. History of Medicine. 2016. Vol. 3. Issue 2. P. 178-184.

\section{References}

Bachynska, L. Yu. (2016). Spivvidnoshennia medychnoi etyky, medychnoi deontolohii ta bioetyky [Correlatoin between Medical Ethics, Medical Deontology and Bioethics]. Naukovyi visnyk Uzhhorodskoho natsionalnoho universytetu. Seriia PRAVOUzhhorod National University Herald. Series: Law, 3, 131-134 [in Ukrainian].

Bila, N. I. (2020). Medychna etyka i deontolohiia: realii i perspektyvy $\mathrm{v}$ roboti suchasnoho medychnoho pratsivnyka [Medical Ethics and Deontology: Realities and Prospects in the Work of a Modern Medical Professional]. Aktualni problem metodolohii vyshcho $i$ medychnoi (farmatsevtychnoi) osvity: suchasni vyklyky ta novi mozhlyvosti - Current Problems of the Methodology of Higher Medical (Pharmaceutical) Education: Modern Challenges and New Opportunities, 88-92 [in Ukrainian].

Bushlja, A. A., \& Budarin, G. Ju. (2012). Jetika Paracel'sa [Ethics of Paracelsus]. Social'noe i pensionnoe pravo - Social and Pension Law, 1 (9), 56-66 [in Russian].

Verbovska, R. I. (2019). Istorychni peredumovy zarodzhennia medychnoi deontolohii v antychnyi period [Historical Preconditions of the Origin of Medical Deontology in the Ancient Period]. Ukrainskyi zhurnal medytsyny, biolohii ta sportu Ukrainian Journal of Medicine, Biology and Sports, 2 (4), 236-241 [in Ukrainian].

Helsinska deklaratsiia VMA «Etychni pryntsypy medychnykh doslidzhen za uchastiu liudyny u yakosti obiekta doslidzhennia» [WMA Declaration of HelsinkiEthical Principles For Medical Research Involving Human Subjects]. (n.d.). $z a$ kon.rada.gov.ua. Retrieved from https://zakon.rada.gov.ua/laws/show/990_005.

Huzhva, O. I. (2021). Rozvytok idei deontolohii ta profesiinoi etyky $\mathrm{v}$ istorychnomu aspekti [Development of Ideas of Deontology and Professional Ethics in Historical Aspect]. Visnyk Luhanskoho natsionalnoho universytetu imeni Tarasa Shevchenka. Pedahohichni nauky - Bulletin of Luhansk Taras Shevchenko National University. Pedagogical Sciences, 6 (344), 1, 17-24 [in Ukrainian].

Deklaratsiia stosovno nezalezhnosti ta profesiinoi svobody likaria [WMA Declaration on Physician Independence and Professional Freedom]. (n.d.). zakon.rada.gov.ua. Retrieved from https://zakon.rada.gov.ua/laws/show/995_326.

Dudikova, L. V. (2017). Rozvytok moralno-etychnykh pohliadiv nalikarskudiialnist $\mathrm{v}$ istory chniispadshchyni [Development of Moral and Ethical Views on Medical Activity in the Historical Heritage]. Profesiina pidhotovka fakhivtsiv: kreatyvnyi pidkhid - Professional Training: a Creative 
Approach. (pp. 319-335). Zhytomyr [in Ukrainian].

Etychnyi kodeks likaria Ukrainy [Ethical Code of Ukrainian Doctor]. (n.d.). zakon.rada.gov.ua. Retrieved from https://zakon.rada.gov.ua/rada/show/n00017 48-09.

Zhenevskaia deklaratsyia [WMA Declaration of Geneva]. (n.d.). zakon.rada.gov.ua. Retrieved from https://zakon.rada.gov.ua/laws/show/990_001.

Ibragimova, H., \& Abdurahimova, N. (2019). Razvitie etiki i deontologii [Development of Ethics and Deontology]. $\mathrm{Mi}$ rovaja nauka - World Science, 6 (27), 197200 [in Russian].

Kolisnyk-Humeniuk, Yu. I. (2010). Moralno-etychna skladova profesiinoi kultury medychnykh pratsivnykiv [Moral and Ethical Component of Professional Culture of Medical Workers]. Problemy ta perspektyvy formuvannia natsionalnoi humanitarnotekhnichnoi elity: zbirnyk naukovykh prats Problems and Prospects of Formation of the National Humanitarian and Technical Elite: Collection of Scientific Works, 27 (31), 2, 213-219 [in Ukrainian].

Kostomarova, E. V. (2013). Sushhnost'i s oderzhanie deontologicheskoj kompetentnosti studenta-medika [The Essence and Content of Deontological Competence of a Medical Student]. Mezhdunarodnyj nauchno-issledovatel'skij zhurnal - International Research Journal, 8-3 (15), 111113 [in Russian].

Kotvitska, A. A., Kubarieva, I. V., \& Horbanov, V. V. (2019). Doslidzhennia istorychnykh aspektiv stanovlennia ta rozvytku farmatsevtychnoi etyky i deontolohii v Starodavnomu sviti [Research of Historical Aspects of Formation and Development of Pharmaceutical Ethics and Deontology in the Ancient World]. Sotsialna farmatsiia: stan, problemy ta perspektyvy - Social
Pharmacy: Status, Problems and Prospects. (pp. 74-82). Kharkiv: NFaU [in Ukrainian].

Levenets, S. S. (2012). Medychna etyka I deontolohiia: realii i perspektyvy v roboti likaria [Medical Ethics and Deontology: Realities and Prospects in the Work of a Doctor]. Medychna osvita - Medical Education, 4, 87-90 [in Ukrainian].

Lyssabonskaia deklaratsyia otnosytelno prav patsyenta [WMA Declaration of Lisbon on the Rights of the Patient]. (n.d.). zakon.rada.gov.ua. Retrieved from https://zakon.rada.gov.ua/laws/show/990_01 6 [in Russian].

Madrydskaia deklaratsyia otnosytelno professyonalnoi avtonomyy y samoupravlenyia [WMA Declaration of Madrid on Professional Autonomy and Self-Regulation]. (n.d.). $z a$ kon.rada.gov.ua. Retrieved from https://zakon.rada.gov.ua/laws/show/990_025 [in Russian].

Mizhnarodnyi kodeks medychnoi etyky [WMA International Code of Medical Ethics]. (n.d.). zakon.rada.gov.ua. Retrieved from https://zakon.rada.gov.ua/laws/show/990_002 [in Ukrainian].

Mudrov, M. Ja. (1968). Slovo o sposobeuchit' iuchit'sja medicine prakticheskoj ili dejatel'nomu vrachebnomu iskusstvu priposteljah bol'nyh [Word on the Way to Teach and Study Practical Medicine]. Hrestomatija po istorii mediciny - Reader on the History of Medicine. (p. 94). Moscow: Medicina [in Russian].

Mudrov, M. Ja. (2009). Slovo o blagochestii i nravstvennyh kachestvah gippokratova vracha [Word about Piety and Moral Qualities in Doctors of Hippocrates]. Jeksperimental'naja $i$ klinicheskaja gastrojenterologija - Experimental and Clinical Gastroenterology, 4, 118-126 [in Russian].

Osnovy zakonodavstva Ukrainy pro okhoronu zdorovia: Zakon Ukrainy vid 19.11.92 r. № 2802-XII (redaktsiia vid 20.10.2021 r.) [On the Fundamental Principles of the Ukrain- 
ian Health Legislation: Law of Ukraine No. 2802-XII of 19.11.92 (as amended on 20.10.2021)]. (n. d.). zakon.rada.gov.ua. Retrieved from https://zakon.rada.gov.ua/laws/show/2801-12 [in Ukrainian].

Polozhenye o zashchyte prav y konfydentsyalnosty patsyenta [Regulations on the Protection of the Rights and Confidentiality of the Patient]. (n.d.). zakon.rada.gov.ua. Retrieved from https://zakon.rada.gov.ua/laws/show/990_056 [in Russian].

Ponomareva, A. A., \& Shtukert, V. V. (2019). Istoricheskie korni formirovanija deontologicheskih i jeticheskih aspektov vrachebnoj dejatel'nosti [Historical Roots of the Formation of Deontological and Ethical Aspects of Medical Practice]. Dolg vracha - Doctor's Duty. (pp. 87-93). Kursk [in Russian].

Pro Kliatvu likaria [About the Doctor's Oath]. (n.d.). zakon.rada.gov.ua. Retrieved from https://zakon.rada.gov.ua/laws/show/349/92 [in Ukrainian].

Tokiiska deklaratsiia [WMA Declaration of Tokyo]. (n.d.). zakon.rada.gov.ua. Retrieved from https://zakon.rada.gov.ua/laws/show/990_011 [in Ukrainian].

Cheban, V. (2014). Istorychnyi aspect likarskoi etyky, bioetyky ta medychnoi deontolohii [Historical Aspects of Medical Ethics, Bioethics and Medical Deontology]. Aktualni pytannia suspilnykh nauk ta istorii medytsyny - Current Issues of Social Sciences and History of Medicine, 3 (3), 93100 [in Ukrainian].

Biryukov, A., Biryukova, N., \& Nesterova, O. (2020). Evolution of ethical and deontological principles in the practice of medical workers based on priest-doctors life experience. European Journal of Science and Theology, 16 (6), 121-129 [in English].

Biryukova, N. V., Kharina, A. S., Nesterova, N. V., \& Malakhovskiy, V. V. (2021). Historical aspects and features of deontology in preventive medicine. Journal of Advanced Pharmacy Education and Research, 11 (3), 77-82 [in English].

Çipi, B. (2015). Deontology and its role in practice medicine in Albania. JAHR, 6/2 (12), 367-374 [in English].

Panova, E. L. (2016). On several prerequisites for the emergence of rational medicine according to Hippocratic Corpus. History of Medicine, 3 (2), 178-184 [in English].

$* * *$

Гужва О. I. Історичні передумови формування деонтологічної компетентності фахівців у галузі охорони здоров'я

У статті розкрито історичні передумови формування деонтологічної компетентності фахівців у галузі охорони здоров'я як властивості особистості медичного працівника, що дозволяє йому продуктивно взаємодіяти із внутрішнім (професійним) і зовнішнім (соціальним) середовищем, забезпечує успішну особистісно-професійну взаємодію з пацієнтами та ефективну організацію та вирішення професійних завдань.

Розглянуто особливості етичних поглядів та деонтологічних моделей, що існували в охороні здоров'я впродовж історичного розвитку людства; окреслено сутність гіппократівської етики та їі подальший розвиток. Проаналізовано основні міжнародні та національні нормативно-правові документи та етичні кодекси, що є основою регулювання взаємин між лікарем і пацієнтом та визначають структуру деонтологічних компетентностей.

Визначено, що морально-етичні принципи та правила професійної поведінки в галузі охорони здоров'я формувалися, змінювалися та вдосконалювалися впродовж історичного розвитку, водночас відбувався зсув акценту 3 міжособистісних взаємин пацієнта та лікаря на забезпечення етичності всієї системи охорони здоров'я. 
Ключові слова: історичні передумови, етика, деонтологія, охорона здоров'я, деонтологічна компетентність, фахівці в галузі охорони здоров'я.

Гужва Е. И. Исторические предпосылки формирования деонтологической компетентности специалистов в области здравоохранения

В статье раскрыты исторические предпосылки формирования деонтологической компетентности специалистов в области здравоохранения как свойства личности медицинского работника, которая позволяет ему продуктивно взаимодействовать с внутренней (профессиональной) и внешней (социальной) средой, обеспечивает успешное личностнопрофессиональное взаимодействие с пациентами, эффективную организацию и решение профессиональных задач.

Рассмотрены особенности этических взглядов и деонтологических моделей, которые существовали в здравоохранении на протяжении исторического развития человечества; очерчена сущность гиппократовской этики и ее дальнейшее развитие. Проанализированы основные международные и национальные нормативноправовые документы и этические кодексы, выступающие основой регулирования взаимоотношений между врачом и пациентом и определяющие структуру деонтологических компетентностей.

Определено, что морально-нравственные принципы и правила профессионального поведения в области здравоохранения формировались, изменялись и совершенствовались на протяжении исторического развития, при этом происходило смещение акцента с межличностных взаимоотношений врача и пациента на обеспечение этичности всей системы здравоохранения.
Ключевые слова: исторические предпосылки, этика, деонтология, здравоохранение, деонтологическая компетентность, специалисты в области охраны здоровья.

Huzhva O. I. Historical Preconditions for the Formation of Deontological Competence of Specialists in the Field of Health Care

The article reveals the historical preconditions for the formation of deontological competence of health professionals as a personality trait of the health workers, which allows them to interact productively with internal (professional) and external (social) environment, provides successful personal and professional interaction with patients and effective organization and solving professional problems.

The peculiarities of ethical views and deontological models that have existed in health care during the historical development of mankind have been considered; the essence of Hippocratic ethics and its further development have been outlined. The main international and national legal documents and codes of ethics, which are the basis for regulating the relationship between doctor and patient, and determine the structure of deontological competencies, have been analyzed.

It has been determined that the moral and ethical principles and rules of professional behaviour in the field of health care have been formed, changed and improved over the course of historical development, shifting the emphasis from the interpersonal relationship between patient and doctor to ensure the ethics of the entire health care system.

Keywords: historical prerequisites, ethics, deontology, health care, deontological competence, health professionals. 